\title{
Immobilization of Norwegian Reindeer (Rangifer tarandus tarandus) and Svalbard Reindeer (R. t. platyrhynchus) with Medetomidine and Medetomidine-Ketamine and Reversal of Immobilization with Atipamezole
}

\author{
By N.J.C. Tyler, R. Hotvedt, A. S. Blix and D. R. Sørensen \\ Department of Arctic Biology, Institute of Medical Biology and University Hospital, \\ University of Tromsø, Norway.
}

\begin{abstract}
Tyler, N. J. C., R. Hotvedt, A. S. Blix and D. R. Sørensen: Immobilization of Norwegian reindeer (Rangifer tarandus tarandus) and Svalbard reindeer ( $R$. t. platyrhynchus) with medetomidine and medetomidine-ketamine and reversal of immobilization with atipamezole. Acta vet. scand. 1990, 31, 479-488. - The sedative action of medetomidine (-ketamine) was studied in 12 captive Norwegian semidomesticated reindeer (NR), including 4 newborn calves, and in 7 free-living Svalbard reindeer (SR). Medetomidine, with or without ketamine, caused effective, reliable immobilization in NR. Doses of $50-200 \mu \mathrm{g} / \mathrm{kg}$ medetomidine alone or $30-125 \mu \mathrm{g} / \mathrm{kg}$ medetomidine combined with $\geqslant 300 \mu \mathrm{g} / \mathrm{kg}$ ketamine induced complete immobilization, good muscle relaxation and persistent, deep sedation with little respiratory depression in NR; SR required higher doses. Atipamezole successfully antagonized medetomidine (-ketamine) resulting in rapid and persistent reversal of immobilization in all cases (NR and SR). Both medetomidine and atipamezole had wide safety margins and no conspicuous lasting side effects after reversal.
\end{abstract}

anaesthesia; sedation; ungulates.

\section{Introduction}

Medetomidine', 4-[1-(2,3-dimethylphenyl)ethyl]-1H-imidazole, is a novel, selective and specific alpha 2 -adrenoreceptor agonist (Lammintausta et al. 1989, Savola et al. 1986, Virtanen et al. 1988) which acts by modulating noradrenaline release on adrenergic terminals in the central nervous system (Scheinin et al. 1986). It is a potent sedative and analgesic agent with muscle-relaxing properties in dogs (Vainio et al. 1987) and cats (Stenberg et al. 1987) and has dose-

1 Medetomidine Farmos Group Ltd., Turku, Finland. dependent sedative effects in humans (Scheinin et al. $1987 \mathrm{a}, \mathrm{b})$.

Atipamezole $^{2}$ (code MPV-1248, 4-(2-ethyl2,3-dihydro- $1 \mathrm{H}$-inden-2-yl)-1 $\mathrm{H}$-imidazole) is a potent, highly selective antagonist at both central and peripheral alpha 2 -adrenoreceptors (Virtanen \& MacDonald 1987) which effectively reverses the sedative effects of medetomidine and medetomidine-ketamine in small mammals (Fargetton \& VähäVahe 1989).

2 Atipamezole Farmos Group Ltd., Turku, Finland. 
Recently, Jalanka (1988) showed that medetomidine was effective and safe for chemical restraint of markhors (Capra falconeri megaceros) when combined with ketamine. The drug is therefore potentially an attractive alternative to etorphine, which, though effective in immobilizing several species of large ungulates including Svalbard reindeer (Øen, personal communication), is highly toxic in humans. This paper reports the effects of medetomidine (-ketamine) and atipamezole in Norwegian and Svalbard reindeer.

\section{Materials and methods \\ Animals}

Medetomidine or medetomidine-ketamine was administered to 12 Norwegian semidomesticated reindeer (NR): 7 adult females (1 pregnant and 6 non-pregnant, non-lactating (NPNL)), one $2 \mathrm{yr}$ old male and 4 calves ( 2 males and 2 females aged 5-15 days), and to 7 Svalbard reindeer (SR) (three $1 \mathrm{yr}$ old females NPNL, 1 pregnant and 1 lactating adult female, one $1 \mathrm{yr}$ old male and 1 adult male) between August 1987 and May 1989. Norwegian reindeer were held in outdoor paddocks at the Department of Arctic Biology, where the calves were born, and were fed a concentrated ration (RF-71, $\mathrm{Ja}$ cobsen \& Skjenneberg 1979) with water/snow ad libitum, for not less than 4 months prior to the trials. They were tame and accustomed to being handled. Trials with Svalbard reindeer were carried out in Adventdalen, Svalbard $\left(78^{\circ} \mathrm{N}\right)$ on free-living wild animals.

\section{Drug administration}

Medetomidine hydrochloride (1 or 10 $\mathrm{mg} / \mathrm{ml}$ ) was used alone or combined (in the same syringe) with ketamine (Ketalar ${ }^{\circledR 3}, 50$

${ }^{3}$ Ketalar $\bullet 50$ or $100 \mathrm{mg} / \mathrm{ml}$, Parke Davis \& Co., Pontypool, Gwent, United Kingdom. or $100 \mathrm{mg} / \mathrm{ml})$. A concentrated stock solution of medetomidine $(30 \mathrm{mg} / \mathrm{ml})$ was diluted to $0.3 \mathrm{mg} / \mathrm{ml}$ with isotonic saline in trials with newborn calves. In winter trials with Svalbard reindeer the solution (30 $\mathrm{mg} / \mathrm{ml}$ ) was mixed 5 parts medetomidine to 1 part $96 \%$ ethanol to prevent freezing. Medetomidine-ketamine mixtures were prepared in the same syringe within $15 \mathrm{~min}$ of use; drug ratios $(\mathrm{w} / \mathrm{w})$ varied from 1:9 $1: 30$. The drug were injected either by hand into M. gluteobiceps while the animals were lightly restrained (NR) or into the hindquarters using a projectile syringe fired from a compressed-air rifle (Injekta junior, Norinject, Hølen, Norway (SR)). With one exception atipamezole $(5 \mathrm{mg} / \mathrm{ml})$ was injected by hand into M. gluteobiceps. Doses of medetomidine, ketamine and atipamezole are summarized in Table 1 . In addition, lidocain (Xylocain ${ }^{\mathbb{2} 4}, 10 \mathrm{mg} / \mathrm{ml}$ ) was administered during ovariectomy of newborn calves (below).

\section{Trials}

Norwegian reindeer $\geqslant 2$ yrs. Twentyone experiments were conducted; 6 outdoors (ambient temperature $0-14^{\circ} \mathrm{C}$ ) and 7 indoors for evaluation of medetomidine (-ketamine) and atipamezole and 8 indoors in conjunction with minor surgery. A minimum of 3 days elapsed between trials on any one animal and in most cases in interval between trials was considerably longer. All animals were weighed to $0.1 \mathrm{~kg}$ on an electronic balance (Sauter KOM-System AZ/N2E, Sauter $\mathrm{GmbH}$, Albstadt-Ebingen) before immobilization. Food was not withheld prior to trials.

Newborn calves. Four experiments were conducted, 1 on each animal, in conjunction

${ }^{4}$ Xylocain ${ }^{\star}, 10 \mathrm{mg} / \mathrm{ml}$, Astra, Sodertalje, Sweden. 
with surgery (castration/ovariectomy). Animals were weighed to $0.1 \mathrm{~kg}$ on a $30 \mathrm{~kg} \times 0.1$ kg steel yard.

Svalbard reindeer. Seven experiments were conducted in the field (ambient temperature -7 to $\left.+6^{\circ} \mathrm{C}\right)$ for evaluation of medetomidine (-ketamine) and atipamezole. In winter trials animals were weighed to $0.5 \mathrm{~kg}$ on a $150 \times 0.5 \mathrm{~kg}$ steel yard; in summer trials live weights were estimated from a growth curve (Tyler 1987).

Times from injection of sedative until (1) the animals showed first signs of sedation (FSS), (2) lay down, (3) to the onset of deep sedation (ODS: when they could be handled without arousal), (4) to injection of antagonist and from injection of antagonist (5) to arousal and (6) to when the animals were on their feet and able to walk and coordinate in a directed manner were recorded with a stop watch. The degree and quality of sedation and immobilization were evaluated according to Jalanka (1988): (a) no effect, (b) insufficient - animal sedated but able to struggle vigorously or get up, (c) moderate - animal sedated but responded to nociceptive stimuli and capable of mild struggling when handled, (d) complete immobilization and deep sedation - good muscle relaxation and no arousal in response to handling or nociceptive stimuli. Depth of sedation was tested using eye- and ear-flicking reflexes. Rectal temperature $\left(T_{b}, 15 \mathrm{~cm}\right.$ inside the rectum) was measured and recorded continuously by copper-constantan thermocouples connected to a Leeds and Northrup type 250 multipoint recorder. All animals were observed periodically for several $h$ after reversal and (NR) daily during routine management and any possible adverse effects of immobilization or reversal were recorded.

\section{Analysis of data}

Results are presented as means $\pm \mathrm{SE}$. Response times (2 sample tests) were compared with Mann-Whitney $U$ tests (Siegel 1956). Respiration rates at different intervals during anaesthesia were compared with Kruskal-Wallis test (Siegel 1956). FSS/ODS ratios were analysed after transformation to arcsin. Parameters in dose-response linear regression models were compared using the $t$ statistic (Kleinbaum \& Kupper 1978). $\mathrm{H}_{\mathrm{o}}$ was rejected at $\mathrm{p}>0.05$ in all tests.

\section{Results}

\section{Immobilization}

Norwegian reindeer $\geqslant 2$ yrs. Both medetomidine-ketamine and medetomidine alone induced complete immobilization and deep sedation in NR. The mean weight of animals during all 21 trials was $61.9 \pm 2.9$ kg. With 4 exceptions deep sedation occurred within 3.5 to $12 \mathrm{~min}$ (Fig. 1). In only 1 case (not included in Fig. 1) an animal failed to respond to a single dose of medetomidine

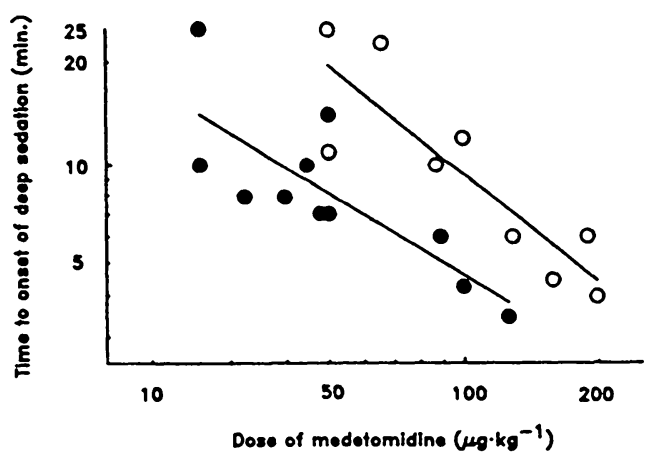

Figure 1. Dose-response curves for sedation following im injection of medetomidine $(\mathrm{O})$ or medetomidine-ketamine $(\bullet)$ in Norwegian reindeer aged $\geqslant 2$ yr. Logarithmic linear regression models $(\mathrm{Y}=\mathrm{a}+\mathrm{bX})$ are: Medetomidine $\mathrm{a}=3.130^{* * *}, \mathrm{~b}=$ $-1.079 * *, r^{2}=0.763$; medetomidine-ketamine $\mathrm{a}=$ $2.306^{* * *}, \mathrm{~b}=-0.820^{* *}, \mathrm{r}^{2}=0.644$. The significance of parameters is shown as ${ }^{* *}=p<0.01$, $* * *=\mathrm{p}<0.001$. 
beyond slight sedation; a similar dose (60 $\mu \mathrm{g} / \mathrm{kg}$ ) given $13 \mathrm{~min}$ after the first induced deep sedation within 3 min.

The induction period was invariably calm. Animals displayed signs of sedation (slight droop of the head, uncertain gait, reduced alertness, slight swaying while standing) within 2-12 minutes, depending on the dose, and then lay down carefully, usually becoming laterally recumbent at once. Time from injection of sedative to first signs of sedation was $44.3 \pm 0.1 \%$ of time to onset of deep sedation $(n=17)$. FSS/ODS ratios did not differ significantly between treatments (medetomidine or medetomidine-ketamine, $p>0.6$ ). Response times (time to onset of deep sedation) tended to be shorter with medetomidine-ketamine than with medetomidine alone but neither the slopes nor the intercepts of $\log / \log$ dose-response linear regression models differed significantly (slopes: $t_{[16]}=0.850, \mathrm{p}>0.1$; intercepts $t_{[16]}=$ $1.433, \mathrm{p}>0.1$; Fig. 1 ).

Loss of consciousness increased simultaneously with the development of complete immobility and muscle relaxation, which was good throughout in all cases. Eye- an earflicking reflexes were abolished completely and there was no arousal following handling (medetomidine-ketamine and medetomidine) or minor surgery (medetomidine alone, $\geqslant 80 \mu \mathrm{g} / \mathrm{kg}$ ). Sedation persisted without diminishing until injection of antagonist in all cases. Maximum length of time for which the animal were maintained under sedation (time from onset of deep sedation to the injection of antagonist) were $48 \mathrm{~min}$ with medetomidine-ketamine (doses medetomidine $=50 \mu \mathrm{g} / \mathrm{kg}$, ketamine $=500 \mu \mathrm{g} / \mathrm{kg}$ ) and 64 min with medetomidine alone (dose = $130 \mu \mathrm{g} / \mathrm{kg}$ ).

Respiration was shallow throughout and, in most cases, irregular with periods of apnoea for up to $30 \mathrm{~s}$ for at least $30 \mathrm{~min}$ after seda-

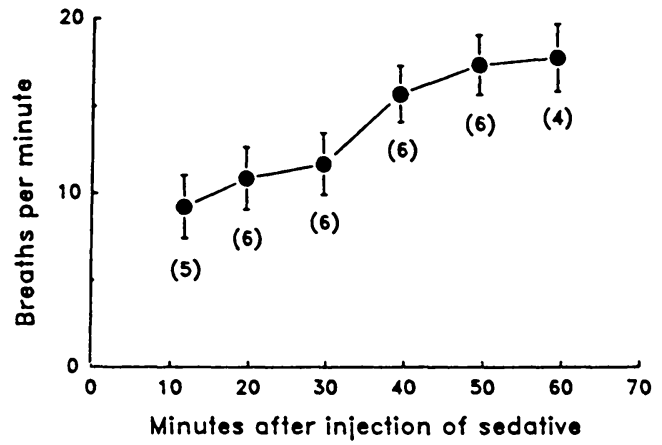

Figure 2. Respiration rate (breaths per minute: in Norwegian reindeer aged $\geqslant 2 \mathrm{yr}$ sedated indoors $\left(\mathrm{T}_{\mathrm{a}}=18^{\circ} \mathrm{C}\right)$ in winter with medetomidine or medetomidine-ketamine. Data are means (circles) $\pm \mathrm{SE}$ (vertical bars) and (number of animals).

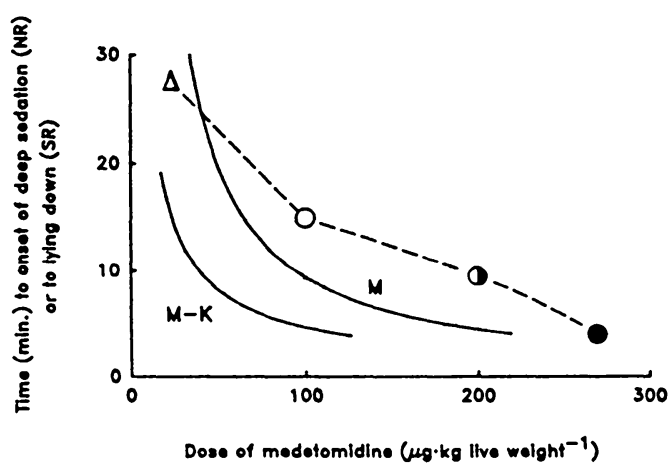

Figure 3. Dose-response curves for sedation following im injection of medetomidine or medetomidine-ketamine in Norwegian reindeer aged $\geqslant 2$ yr (NR) and in Svalbard reindeer (SR). NR (solid lines): time from injection of sedative to onset of deep sedation. The 2 curves, drawn from logarithmic regression models (Fig. 1), show results using medetomidine (M) and medetomidine (M-K). SR (dotted line): time from injection of sedative to when animals first lay down. Symbols indicate results following injection of medetomidine-ketamine (triangle) and medetomidine alone (circles). The degree of sedation achieved in each case is indicated as insufficient (open symbols), moderate (half filled symbol) or complete (filled symbol). 
Table 1. Doses ( $\mu \mathrm{g} / \mathrm{kg}$ live weight) of medetomidine, medetomidine-ketamine and atipamezole in Norwegian reindeer $(\mathrm{NR})$ aged $\geqslant 2$ years and Svalbard reindeer $(\mathrm{SR})$.

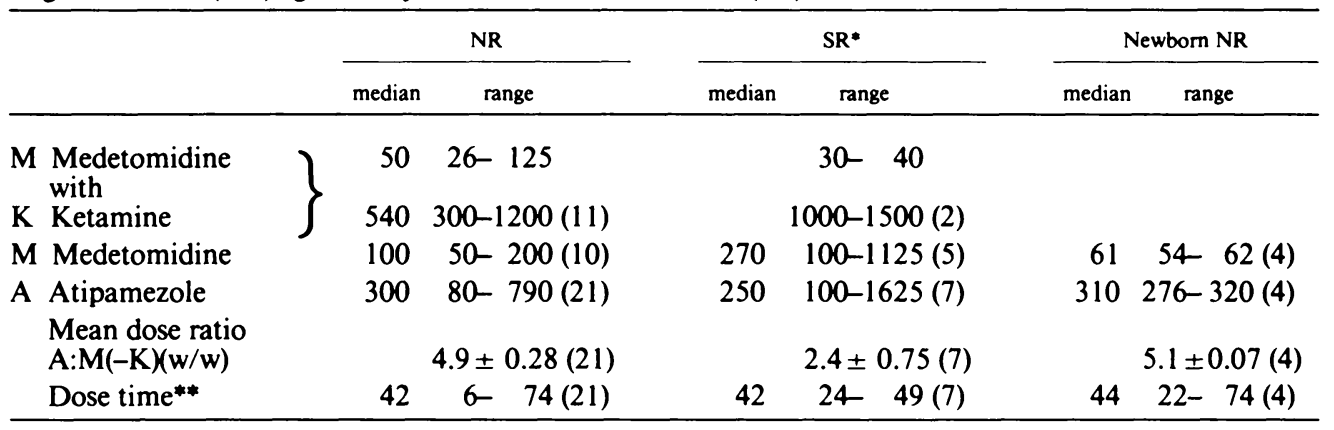

* doses are based on estimated live weight in five cases (see Materials and Methods).

** time from injection of sedative to injection of antagonist (min).

() number of trials.

tion. Respiration rates during indoor trials in winter increased from $9.2 \pm 1.8$ breaths per $\min (\mathrm{bpm}, \mathrm{n}=5)$ at $\mathrm{t}=12 \mathrm{~min}$ to $17.8 \pm$ $1.9 \mathrm{bpm}(\mathrm{n}=4)$ at $60 \mathrm{~min}(\mathrm{H}=14.378, \mathrm{df}=$ $5, \mathrm{p}<0.02$; Fig. 2). Corresponding $\mathrm{T}_{\mathrm{b}}(\mathrm{n}=$ 2) increased from 38.7 and $39.4^{\circ} \mathrm{C}$ at $\mathrm{t}=15$ min to 39.3 and $39.5^{\circ} \mathrm{C}$, respectively, at $\mathrm{t}=$ 60 min (ambient temperature, $\mathrm{T}_{\mathrm{a}}=18.4^{\circ} \mathrm{C}$ ).

Ruminal tympany during sedation was without clinical significance and was not detectable after reversal. No uncontrolled regurgitations occurred.

Newborn calves. Intra-muscular doses of $54-62 \mu \mathrm{g} / \mathrm{kg}$ medetomidine (Table 1) induced complete immobilization and deep, persistent sedation in all 4 calves (live weight = $8.8 \pm 0.7 \mathrm{~kg}$ ) within $3.5 \mathrm{~min}$. Induction was calm: first signs of sedation occurred in 20-50 s. Local anaesthetic in conjunction with medetomidine alone induced high plane surgical anesthesia. However, in contrast to adults, the ear flicking reflex was never completely abolished. The maximum length of time for which animals were maintained under sedation before injection of antagonist was $71 \mathrm{~min}$.

Svalbard reindeer. In summer trials (July \& August, $\mathrm{n}=5$ ) doses of $30 \mu \mathrm{g} / \mathrm{kg}$ medeto- midine with $1500 \mu \mathrm{g} / \mathrm{kg}$ ketamine or $100-200 \mu \mathrm{g} / \mathrm{kg}$ medetomidine alone sedated SR sufficiently to permit their capture within 10-42 $\mathrm{min}$. Response times (time to lying) in SR were approximately $50 \%$ longer for a given dose of medetomidine than response times (time to onset of deep sedation) in NR (Fig. 3) except in 1 case (not included in Fig. 3) in which an animal lay down $10 \mathrm{~min}$ after injection of $40 \mu \mathrm{g} / \mathrm{kg}$ medetomidine with $1000 \mu \mathrm{g} / \mathrm{kg}$ ketamine. However, deep sedation and complete immobilization occurred only in 1 animal (estimated dose $=270 \mu \mathrm{g} / \mathrm{kg}$ medetomidine; Fig. 3). With this exception SR remained conscious, sometimes struggling vigorously when handled, until antagonist was injected. Estimated live weights of the animals were: adults $=45-80 \mathrm{~kg}, \mathrm{n}=3$; yearlings $=30 \mathrm{~kg}, \mathrm{n}$ $=2$.

SR respond differently in winter (April, $\mathrm{n}=$ 2). One animal (female, 34 mo., pregnant) showed mild (insufficent) sedation after 30 min (dose medetomidine $=300 \mu \mathrm{g} / \mathrm{kg}$ ) but remained capable of evading capture for a further $45 \mathrm{~min}$. A similar dose given $75 \mathrm{~min}$ after the first induced deep sedation after 10 
min. Both darts struck the animal high on the rump and injected the anaesthetic without leakage or bleeding. A second animal (female, 22 months old, non-pregnant), struck in the ventral abdominal region (M. cutaneus trunci) showed no signs of sedation after $72 \mathrm{~min}$ (dose medetomidine = $400 \mu \mathrm{g} / \mathrm{kg}$ ). A second similar dose, injected without leakage into the pelvic limb slightly below the knee, induced moderate sedation after $30 \mathrm{~min}$; a third similar dose, injected into $M$. gluteobiceps, induced deep sedation after $5 \mathrm{~min}$.

The induction period was calm in all cases (summer and winter); animals shook themselves briefly when struck by the dart but usually displayed no overt change in behaviour before onset of sedation, the symptoms of which were similar to those in NR. Ruminal tympany during anaesthesia was without clinical significance and no uncontrolled regurgitations occurred.

\section{Reversal}

Norwegian reindeer $\geqslant 2$ yrs. \& Svalbard reindeer. Intramuscular injection of atipamezole reversed sedation and immobilization effectively and rapidly in all cases. Doses, dose ratios (atipamezole:medetomidine, w/w) and dose times are summarised in Table 1. Times from injection of antagonist to arousal did not differ significantly between NR and SR ( $p>0.9$ ); mean arousal time was $10.4 \pm 1.5 \mathrm{~min}(\mathrm{n}=20)$. Recovery periods were calm. First signs of arousal included minor ear movements and blinking. The animals subsequently lifted their heads, turned onto sternal recumbancy and got up, usually at the first attempt. NR in particular were alert and able to walk in a directed manner (WDM) almost at once. Times from intramuscular injection of antagonist to WDM did not differ significantly between treatments (medetomidine or mede- tomidine-ketamine) in NR ( $p>0.8$ ) or between NR and SR ( $p>0.2)$. Mean time to WDM (NR \& SR) was $12.4 \pm 1.3 \mathrm{~min}(\mathrm{n}=$ 21).

Antagonist was administered by intravenous injection in 1 SR in which deep sedation had been achieved: time to WDM in this animal was $4.5 \mathrm{~min}$. No noteworthy relapses into sedation occurred but SR which received very high (multiple) doses of medetomidine $(600-1000 \mu \mathrm{g} / \mathrm{kg})$ seemed to be rather 'slow' for up to $24 \mathrm{~h}$ after reversal.

All animals (NR and SR) survived not less than 1 month after trials, apparently without ill-effect, except for two SR, including one pregnant female, which were shot 10 days after immobilization for another purpose. The foetus of this female, which was within 4 weeks of full term, appeared quite normal.

Newborn calves. Atipamezole (Table 1) caused rapid, persistent reversal of the effects of medetomidine. Arousal time was 3.4 $\pm 0.7 \mathrm{~min}$ (range $=2.0-5.25 \mathrm{~min}$ ). All animals displayed overalertness and, in one case, heavy painting, for not less than 5-10 min after arousal at which point they were returned to their mothers. All recognised and were accepted by their dams immediately. All survived not less that 6 months after trials.

\section{Discussion}

Medetomidine, with or without ketamine, caused effective, reliable immobilization in Norwegian reindeer. Doses of $50-200 \mu \mathrm{g} / \mathrm{kg}$ medetomidine alone or $30-125 \mu \mathrm{g} / \mathrm{kg}$ medetomidine combined with $\geq 300 \mu \mathrm{g} / \mathrm{kg}$ ketamine induced complete immobilization, good muscle relaxation and persistent, deep sedation. Deep sedation was achieved in SR only with substantially higher doses. Atipamezole successfully antagonized medetomidine (-ketamine), resulting in smooth, rapid 
and persistant reversal of immobilization in all cases (NR and SR), except in very young calves. These displayed considerable overalertness for some min after reversal. Both medetomidine and atipamezole had wide safety margines and no conspicuous lasting side effects after reversal. The combination of characteristics in medetomidine (-ketamine) and atipamezole of high potency, rapid action, good sedation, good reversibility and safety was satisfactory both for capturing reindeer by immobilization and for minor surgery.

The degree of sedation and immobility was good in both subspecies of reindeer (especially NR) using medetomidine alone. This contrasts with 3 species of caprids in which use of medetomidine alone was not satisfactory (Jalanka 1988). Moreover, analgesia during deep sedation was sufficient in reindeer for minor surgery without ketamine or local anaesthetic; local anaesthetic was necessary, however, for abdominal surgery.

The remarkably calm induction period following injection of metetomidine in both reindeer (this study) and markhors (Jalanka 1988 ) is an important feature of sedation with medetomidine, especially for freeranging wild animals which suffer a high risk of injury during panic flight. Response times to medetomidine-ketamine were similar in markhors and NR: mean time to recumbancy was $4.6 \mathrm{~min}$ in markhors (dose $=69 \mu \mathrm{g} / \mathrm{kg}$ medetomidine with $1600 \mu \mathrm{g} / \mathrm{kg}$ ketamine) compared to a mean time to onset of deep sedation with the same dose of $6.3 \mathrm{~min}$ in NR (by regression, Fig. 1). However, Jalanka (1988) recommended that markhors be left undisturbed for 2 to $4 \mathrm{~min}$ after developing recumbency to allow the drugs to take full effect. This was necessary only in NR which had received relatively low doses $(<50 \mu \mathrm{g} / \mathrm{kg})$ of medetomidine. The sedative effect of the drugs was perhaps more per- sistent in reindeer compared to markhors: in these maximum sedation seemed to occur between 20 and $45 \mathrm{~min}$ after darting ( $\mathrm{Ja}$ lanka 1988). In NR and those SR in which deep sedation was achieved, by contrast, maximum effect persisted from onset of deep sedation until antagonist was injection (up to $74 \mathrm{~min}$ after darting).

The small but steady rise in respiration frequency in winter insulated NR anaesthetised indoors (Fig. 2) indicates a thermoregulatory response to hyperthermia due to high ambient temperature rather than a direct effect of medetomidine on the central nervous system. This was confirmed in one case by arise in rectal temperature from $38.7^{\circ}$ to $39.3^{\circ} \mathrm{C}$ after $60 \mathrm{~min}$ sedation. Adult reindeer resting in thermoneutral conditions take about 10 breaths per min (Blix \& Johnsen 1983, Mercer et al. 1985). In our indoor trials $\left(\mathrm{T}_{\mathrm{a}}=18^{\circ} \mathrm{C}\right)$, respiratory frequency increased from that level to about 17 breaths per min, but in this situation the animals were exposed to $\mathrm{T}_{\mathrm{a}}$ almost $60^{\circ} \mathrm{C}$ above their lower critical temperature $\left(-40^{\circ} \mathrm{C}\right.$, Nilssen et al. 1984).

Variation in dose effects can be expected, especially when drugs are administered with projectile syringe due, for example, to local tissue damage or to hitting poorly vascularised parts of the body (e.g. Meuleman et al. 1984). Nevertheless, consistent hyposensitivity to medetomidine in Svalbard reindeer compared to Norwegian animals seems likely to be a genetic effect. Svalbard reindeer diverged from Eurasian tundra reindeer some 225000 years ago (Røed 1985) and are now morphologically quite distinctly different. It would not, therefore, be surprising to find genetic variability in other traits, including responses to particular drugs. Interestingly, these animals are also hyposensitive to xylazine which, like medetomidine, is also an alpha 2 -adrenoreceptor agonist, and 
require doses 30 to 80 times greater than Norwegian reindeer ( $A$. S. Blix, unpublished and $K$. Hove, personal communication). Fletcher (1974) reported a similar example in which an isolated population of deer responded differently to xylazine compared to animals from the original mainland stock. These observations are indicative of major differences in drug deposition, including differences in peripheral vascular receptor sensitivity, degree of plasma protein binding or degradation of the drug in the liver. Such differences in close relatives of the same species invites further investigation.

Rapid, persistent reversal of the effects of medetomidine (-ketamine) by atipamezole is an excellent feature of this anaesthesia, reducing recovery times from several h (e.g. Festa-Bianchet \& Jorgensen 1985, Kreeger et al. 1987) to a few min. Besides being calm, the animals were alert (NR) and normally able to walk in a directed manner as soon as they got up (NR \& SR). There was no sign of muscular tremors, which sometimes occur in markhors after intravenous or combined intravenous-intramuscular injection of atipamezole (Jalanka 1988), or of failure in judging distance, leg stretching or movements backwards as reported after yohimbine (Jessup et al. 1983, Renecker \& Olsen 1986). Reindeer calves, which had very short arousal times $(3.4 \mathrm{~min}$ $\pm 0.7 \mathrm{~min}$ ), showed considerable overalertness immediately after reversal. Jalanka (1988) suggested that overalertness might be a consequence of administering too large a proportion of the antagonist by intravenous injection in cases in which the effects of anaesthesia were already beginning to wear off. In our study, however, antagonist was administered im and all the calves displayed overalertness, including 2 in which the antagonist was administered within $30 \mathrm{~min}$ of onset of deep sedation. With the exception of newborn calves, response times in reindeer were slightly longer than in adult markhors (markhors, im: arousal time $=6.3 \mathrm{~min}$, $\mathrm{WDM}=7.0 \mathrm{~min}$, dose $=323 \mu \mathrm{g} / \mathrm{kg}$ atipamezole, Jalanka 1988; reindeer $\geqslant 2$ yrs, im: arousal time $=10.4 \mathrm{~min}, \mathrm{WDM}=12.4 \mathrm{~min}$, this study). However, response times in reindeer are perfectly satisfactory for practical purposes where the main requirement is to have animals up, alert and behaving normally as quickly as possible.

\section{Acknowledgements}

Dr. T. Vähä-Vahe, Farmos Group Ltd., kindly provided the medetomidine and atipamezole used in this study. H. Jalanka read and criticised an earlier version of this paper.

\section{Reference}

Blix AS, Johnsen HK: Aspects of nasal heat exchange in reindeer. J. Physiol. (Lond.) 1983, 340, 445-454.

Fargetton $X$, Vähä-Vahe $T$ : Medetomidine and atipamezole in small animal practice. J. Royal Netherlands vet. Assoc. 1989, 114 (Suppl. 1), 91S-93S.

Fletcher J: Hypersensitivity of an isolated population of red deer (Cervus elaphus) to xylazine. Vet. Rec. 1974, 94, 85-86.

Festa-Bianchet $M$, Jorgensen JT: Use of xylaxine and ketamine to immobilize bighorn sheep in Alberta. J. Wildl. Manage. 1985, 49, 162165.

Jacobsen E, Skjenneberg S: Forsøk med ulike forrblanding til rein. Fôrverdi av reinfôr (RF-71). (Experiments with different diets to reindeer. Feeding value of reindeer feed (RF-71)). Meld. Norges landbrukshøgskole 1979, 58, 1-11.

Jalanka $\mathrm{H}$ : Evaluation of medetomidine- and ketamine-induced immobilization in markhors (Capra falconeri megaceros) and its reversal by atipamezole. J. zoo amin. Med. 1988, 19, 95-105.

Jessup DA, Clark WE, Gullet PA, Jones KR: Immobilization of mule deer with ketamine and 
xylazine, and reversal of immobilization with yohimbine. J. amer. vet. med. Assoc. 1983, 183, 1339-1340.

Kleinbaum DG, Kupper LL: Applied regression analysis and other multivariable methods. 1978, Duxbury Press, Massachusetts, 486 pp.

Kreeger TJ, Plotka ED, Seal US: Immobilization of white-tailed deer by etorphine and xylazine and its antagonism by nalmefene and yohimbine. J. Wild. Dis. 1987, 23, 619-624.

Lammintausta $R$, Vainio $O$, Virtanen $R$, VähäVahe $T$ (Eds.): Medetomidine, a novel alpha2agonist for veterinary sedative and analgesic use. Acta vet. scand. 1989, Suppl. 85, 1-202.

Mercer JB, Johnsen HK, Blix AS, Hotvedt R: Central control of expired air temperature and other thermoregulatory effectors in reindeer. Am. J. Physiol. 1985, 248 (Regulatory Integrative Comp. Physiol. 17), R679-R685.

Meuleman T, Port JD, Stanley TH, Williard KF: Immobilization of elk and moose with carfentanil. J. Wildl. Manage. 1984, 48, 258-262.

Nilssen KJ, Sundsfjord JA, Blix AS: Regulation of metabolic rate in Svalbard and Norwegian reindeer. Am. J. Physiol. 1984, 247 (Regulatory Integrative Comp. Physiol. 16), R837R841.

Renecker LA, Olsen CD: Antagonism of xylazine hydrochloride with yohimbine hydrochloride and 4-aminopyridine in captive wapiti. J. Wildl. Dis. 1986, 22, 91-96.

Røed $K H$ : Comparison of the genetic variation in Svalbard and Norwegian reindeer. Can. J. Zool. 1985, 63, 2038-2042.

Savola J-M, Ruskoaho H, Puurunen J, Salonen JS, Kärki NT: Evidence for medetomidine as a selective and potent agonist at alpha2-adrenoreceptors. J. auton. Pharmac. 1986, 5, 272284.

Scheinin $H$, Virtanen $R$, Scheinin M: Alpha $2-$ adrenoreceptor agonists decrease free 3-methoxy-4-hydroxyphenylglycol in rat cerebrospinal fluid. Eur. J. Pharmac. 1986, 123, 115-121.

Scheinin M, Kallio A, Koulu M, Arstila M, Viikari J, Scheinin $H$ : Dose-finding and tolerability study of medetomidine in four healthy volunteers. Curr. Therap. Res. 1987a, 41, 637646.

Scheinin M, Kallio A, Koulu M, Viikari J, Scheinin $H$ : Sedative and cardiovascular effects of medetomidine, a novel selective alpha2-adrenoreceptor agonist, in healthy volunteers. $\mathrm{Br}$. J. clin. Pharmac. 1987b, 24, 443-451.

Siegel $S$ : Nonparametric statistics for the behavioral sciences. 1956, McGraw-Hill Kogakusha, Tokyo, 312 pp.

Stenberg $D$, Salven $P$, Miettinen MVJ: Sedative action of the alpha2-agonist medetomidine in cats. J. vet. Pharmacol. Therap. 1987, 10, 319323.

Tyler NJC: Body composition and energy balance of pregnant and non-pregnant Svalbard reindeer during winter. Symp. zool. Soc. Lond. 1987, 87, 203-229.

Vainio O, Palmu L, Virtanen R, Wecksell J: Medetomidine, a new sedative and analgesic drug for dogs and cats. J. assoc. vet. Anaesth. (U.K.) 1987, 14, 53-56.

Virtanen $R$, MacDonald $E$ : Reversal of the sedative/analgesic and other effects of detomidine and medetomidine by MPV-1248, a novel alpha 2 -antagonist. Pharmacol. Toxicol. 1987, 60, (Suppl. III), 73.

Virtanen $R$, Savola J-M, Saano, Nyman L: Characterization of the selectivity, specificity and potency of medetomidine as an alpha2-adrenoreceptor agonist. Eur. J. Pharmac. 1988, 150, 9-14.

\section{Sammanfattning}

Immobilisering av Norsk Rein (Rangifer tarandus tarandus) og Svalbardrein (R. t. platyrhynchus) med Medetomidine og Medetomidine-

Ketamine og Reversering av Immobiliseringen med Atipamezole.

Den immobiliserende virkningen av medetomidine (-ketamine) ble undersøkt i 8 voksne norske tamrein (NR) og 4 nyfødte kalver holdt $i$ fangenskap, og i 7 frittlevende Svalbardrein (SR). Medetomidine, med eller uten ketamine, forårsaket en effektiv og sikker immobilisering av NR. Doser på $50-200 \mu \mathrm{g} / \mathrm{kg}$ medetomidine alene eller $30-125$ $\mu \mathrm{g} / \mathrm{kg}$ medetomidine kombinert med $>300 \mu \mathrm{g} / \mathrm{kg}$ 
ketamine førte til fullstendig immobilisering, god muskelavslappning og vedvarende dyp bedøvelse uten respiratorisk depresjon i NR. SR krevde høyere doser. Atipamezole motvirket medetomidine (-ketamine), og resulterte i hurtig reversering av immobiliseringen $i$ alle forsøkene (NR and SR). Både medetomidine og atipamezole hadde store sikkerhetsmarginer, og ingen iøynefallende bivirkninger efter reverseringen. Kombinasjonene av egenskapene til medetomidine (-ketamine) og atipamezole: hurtig virkning, god sedasjon og analgesi, god reversering samt høy sikkerhet, var meget tilfredsstillende både for infanging og for små kirurgiske inngrep.

(Received September 10, 1989; accepted February 1, 1990)

Reprints may be requested from: N. J. C. Tyler, Department of Arctic Biology, University of Tromsø, Breivika, N-9000 Tromsø, Norway. 